\title{
Serpentinites: Mineral Structure, Properties and Technological Applications
}

\author{
Ottavio Raul D. R. Carmignano, ${ }^{a}$ Sara S. Vieira, ${ }^{b}$ Paulo Roberto G. Brandão, ${ }^{c}$ \\ Alexandre C. Bertoli ${ }^{b}$ and Rochel M. Lago ${ }^{\circledR *, b}$ \\ ${ }^{a}$ Doutorado Inovação/Mineradora Pedras Congonhas, Universidade Federal de Minas Gerais, \\ 31270-901 Belo Horizonte-MG, Brazil \\ ${ }^{b}$ Departamento de Química, Instituto de Ciências Exatas, Universidade Federal de Minas Gerais, \\ 31270-901 Belo Horizonte-MG, Brazil \\ ${ }^{c}$ Escola de Engenharia, Universidade Federal de Minas Gerais, \\ 31270-901 Belo Horizonte-MG, Brazil
}

\begin{abstract}
Serpentine is a versatile mineral family rich in $\mathrm{Mg}$ silicate with several polymorphic phases, mainly antigorite and lizardite, all of them with similar chemical composition $\left(\mathrm{Mg}_{3} \mathrm{Si}_{2} \mathrm{O}_{5}(\mathrm{OH})_{4}\right)$. Their structures are generally composed of octahedral layers rich in $\mathrm{Mg}\left[\mathrm{MgO}_{2}(\mathrm{OH})_{4}\right]^{6-}$, attached to a tetrahedral silicate $\left[\mathrm{Si}_{2} \mathrm{O}_{5}\right]^{2-}$ sheet. The unique physicochemical properties of serpentinites and the existence of large reserves in Brazil create new important opportunities for research and technological applications. In this work, serpentinites structures and properties are reviewed, as well as its occurrence and literature describing its applications in construction/ceramics, agriculture, as a silica source, in steel production, as an additive/filler in polymers, in the production of composites, adsorption of cations and organics contaminants, $\mathrm{CO}_{2}$ capture and catalysis. The presence of harmful chrysotile associated with serpentinites, some of its properties and uses are also described.
\end{abstract}

Keywords: serpentine, antigorite, lizardite, chrysotile, silicate minerals

\section{Serpentinite: Structure and Proprieties}

Serpentine is a group of approximately twenty minerals with typical general composition of $\mathrm{Mg}_{3-\mathrm{x}}(\mathrm{M})_{\mathrm{x}} \mathrm{Si}_{2-\mathrm{y}}(\mathrm{T})_{\mathrm{y}} \mathrm{O}_{5}(\mathrm{OH})_{4}$, where the site $\mathrm{M}$ can be occupied by $\mathrm{Mg}^{2+}, \mathrm{Fe}^{2+}, \mathrm{Fe}^{3+}, \mathrm{Al}^{3+}, \mathrm{Ni}^{2+}, \mathrm{Mn}^{2+}, \mathrm{Zn}^{2+}$ and the site $\mathrm{T}$ by $\mathrm{Si}^{4+}, \mathrm{Al}^{3+}, \mathrm{Fe}^{3+}$. ${ }^{2}$ These minerals are formed by hydration of olivine $\left(\left(\mathrm{Mg}^{2+}, \mathrm{Fe}^{2+}\right)_{2} \mathrm{SiO}_{4}\right)$ in rich ultramafic rocks at relatively low temperatures. ${ }^{2,3}$ Other minerals are also present in this group, such as brucite $\left(\mathrm{Mg}(\mathrm{OH})_{2}\right)$, talc $\left(\mathrm{Mg}_{3} \mathrm{Si}_{4} \mathrm{O}_{10}(\mathrm{OH})_{2}\right)$, calcite $\left(\mathrm{CaCO}_{3}\right)$ and magnesite $\left(\mathrm{MgCO}_{3}\right)$; magnetite $\left(\mathrm{Fe}_{3} \mathrm{O}_{4}\right)$ usually is a primary accessory mineral.

The structural unit of serpentines (Figure 1) is a layer with a thickness of $0.72 \mathrm{~nm}$ in which the $\mathrm{Mg}$ trioctahedral sheet $\left[\mathrm{MgO}_{2}(\mathrm{OH})_{4}\right]^{6-}$ is connected to the tetrahedral silicate sheet $\left[\mathrm{Si}_{2} \mathrm{O}_{5}\right]^{2-.3,4} \mathrm{On}$ the other hand, perpendicular to the sheet, tetrahedral-octahedral $(\mathrm{T}-\mathrm{O})$ layers are linked to other $\mathrm{T}-\mathrm{O}$ layers by a weak H-bonding.

The charge counterbalance can lead to a misfit between the $\mathrm{T}$ layers and $\mathrm{O}$ sheets, producing layers either curved

*e-mail: rochel@ufmg.br or flat, which generates different serpentine polymorphs. ${ }^{2,3}$ Lizardite, antigorite, and chrysotile have the same chemical composition, but their different layer curvatures result in fibrous chrysotile, lamellar agglomerated antigorite and lizardite elongated mineral particles., ${ }^{5,6}$

Antigorite is derived from ultrabasic rocks with crystals in colors white, yellow, green or brown and morphologies based on flakes or lath-shaped. It also occurs in massive, fibrous or foliated habits. ${ }^{7}$ Antigorite presents slightly curved layers. The octahedral sheet is continuous, whereas the tetrahedral sheet undergoes periodic alternations, leading to some cross-connection with adjacent octahedral sheets through covalent $\mathrm{Si}-\mathrm{O}$ bonds (Figure 2). ${ }^{2}$

Lizardite has a flat crystal structure favored by coupled substitutions of $\mathrm{Al}^{3+}$ and $\mathrm{Fe}^{3+}$ for $\mathrm{Mg}^{2+}$ and $\mathrm{Si}^{4+}$. Due to the many different ways of stacking lizardite layers, different polytypes are possible. The most common of these forms is the trigonal layer polytype, where successive layers are directly superimposed without any lateral shift (Figure 3). ${ }^{2}$ In this structure, the - $\mathrm{OH}$ groups can be found on the outer surface, at the top of the tri-octahedral sheet, or internal, located between the octahedral and tetrahedral sheets. ${ }^{6}$ 


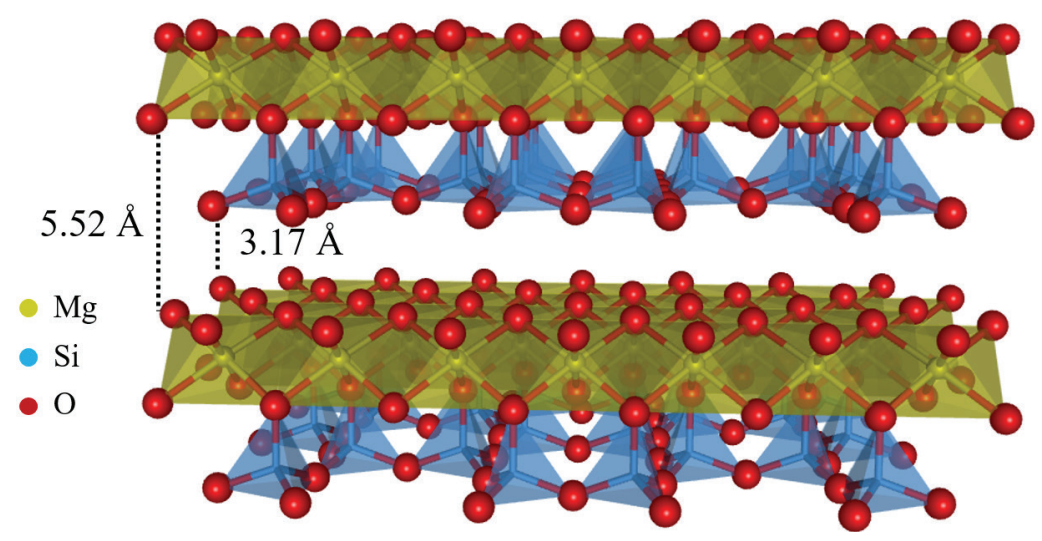

Figure 1. Serpentine basic structure.
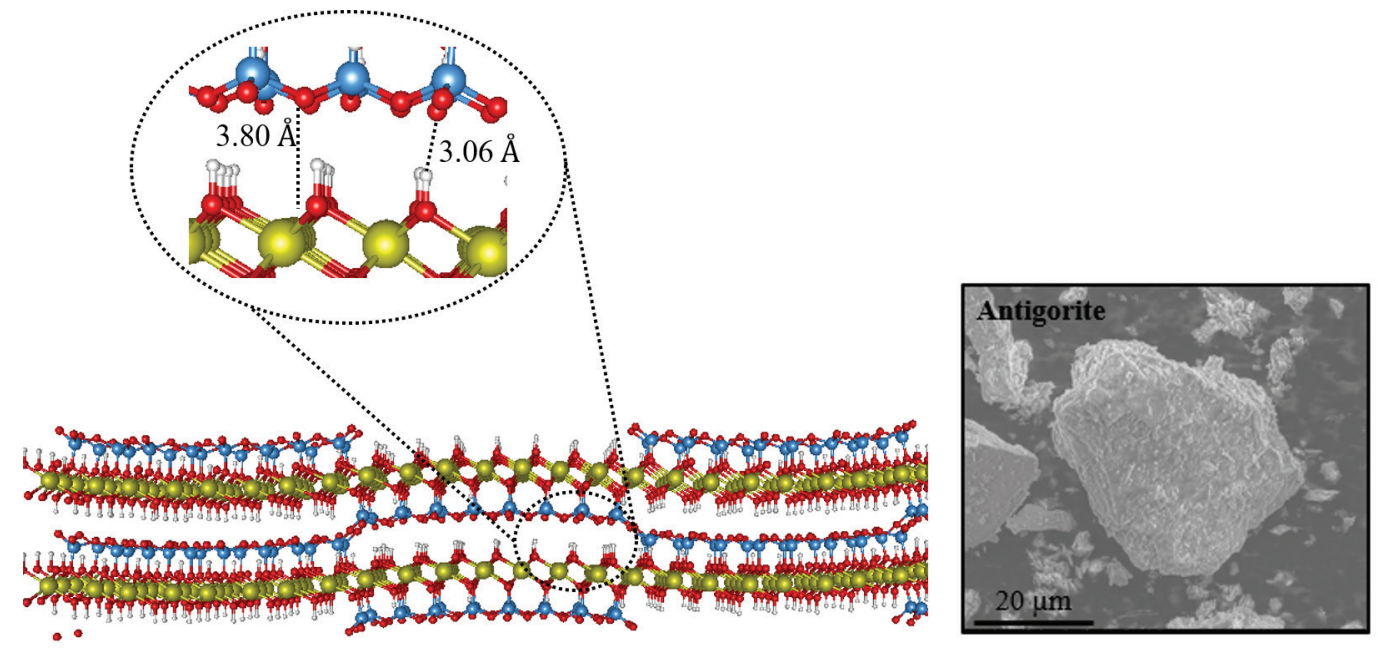

Figure 2. Antigorite structure wave pattern and scanning electron microscopy (SEM) image.

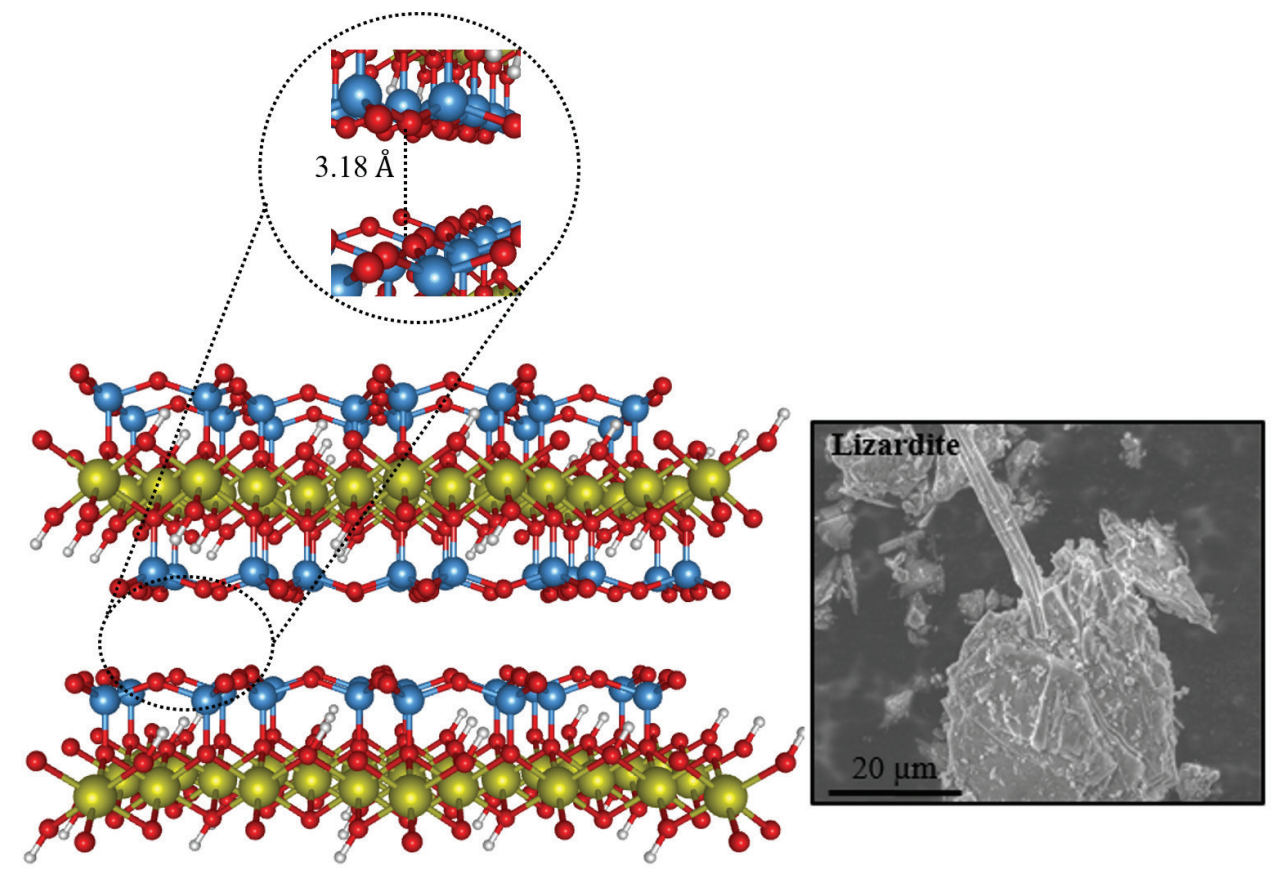

Figure 3. Lizardite: parallel layer structures and scanning electron microscopy (SEM) image. 
The crystalline structure of chrysotile is tubular (Figure 4) due to the winding of the octahedral $\left[\mathrm{Mg}(\mathrm{OH})_{2}\right]$ layers (internal surfaces) and the tetrahedral $\left[\left(\mathrm{Si}_{2} \mathrm{O}_{4}\right)\right]$ (external surfaces) layers that have different crystallographic dimensions in the composition of the unitary cell unit. ${ }^{8,9}$ Its parallel fiber orientation (cross, oblique, or slip) is mostly determined by the repeated opening of fractures. ${ }^{2,10}$ Chrysotile has an outer diameter of approximately $100 \mathrm{~nm}$ and its fibers can reach several centimeters in diameter. Its structure is generally poor in relation to the presence of $\mathrm{Al}^{3+}$ and $\mathrm{Fe}^{3+}{ }^{3}$

\section{Occurrence}

Serpentinites are found in different places in the world, with global reserves estimated in hundreds of millions of tons. ${ }^{3}$ The map in Figure 5 shows the main serpentinite reserves. The most important serpentine group natural deposits occur in Australia, Armenia, Italy, Russia, USA, Canada, Paraguay, New Zealand, and Brazil. ${ }^{12}$

According to Mineral Commodity Summaries, ${ }^{13}$ the estimated global quantity of serpentinite/chrysotile mineral resources is abundant and corresponds to approximately 200 million tons. In Brazil, the minable serpentinite reserve corresponds to $158,425,910$ tons, mainly concentrated in the states of Minas Gerais and Paraná. ${ }^{14}$ Industrial serpentinite sales are mainly for civil construction (ca. 44\%), but also for steel, soil and fertilizer markets. ${ }^{13}$

The serpentinite rocks found in Minas Gerais and Paraná are mainly of the lizardite type; according to the results of inductively coupled plasma-optical emission spectrometry (ICP-OES) analyses, ${ }^{14}$ these samples presented $22.4 \%$ of magnesium in its composition. The chrysotile type of serpentinite is found in the state of Goiás, produced by the company SAMA (Mineração of Amianto Ltda), with reserves of approximately 10,915,000 tons. In the past, this company operated and benefited about 295,000 tons of chrysotile per year. ${ }^{10}$ The state of Goiás possess $100 \%$ of the national reserves of chrysotile asbestos, while the state of Minas Gerais has predominantly industrial serpentinite, which is part of talc and other mineral fillers category. ${ }^{13}$ The company Pedras Congonhas is one of the largest explorers of this mineral in the State of Minas Gerais.

\section{Thermal Behavior of Serpentine}

The thermal decomposition evaluated by thermogravimetric-differential scanning calorimetry (TG-DSC) curves ${ }^{6,15}$ showed an endothermic peak between 300-700 ${ }^{\circ} \mathrm{C}$ which is attributed to the dehydroxylation reaction according to the simplified equation 1 . The formed intermediate, $\mathrm{Mg}_{3} \mathrm{Si}_{2} \mathrm{O}_{7}$, is converted into forsterite $\left(\mathrm{Mg}_{2} \mathrm{SiO}_{4}\right)$ at temperatures above $700{ }^{\circ} \mathrm{C}$ (equation 2). ${ }^{16-19}$

$$
\begin{aligned}
& \mathrm{Mg}_{3} \mathrm{Si}_{2} \mathrm{O}_{5}(\mathrm{OH})_{4(\mathrm{~s})} \rightarrow \mathrm{Mg}_{3} \mathrm{Si}_{2} \mathrm{O}_{7(\mathrm{~s})}+2 \mathrm{H}_{2} \mathrm{O}_{(\mathrm{g})} \\
& 2 \mathrm{Mg}_{3} \mathrm{Si}_{2} \mathrm{O}_{7(\mathrm{~s})} \rightarrow 3 \mathrm{Mg}_{2} \mathrm{SiO}_{4(\mathrm{~s})}+\mathrm{SiO}_{2(\mathrm{~s})}
\end{aligned}
$$

Thermal stability of the serpentinite polymorphs is quite diverse. For lizardite, chrysotile and antigorite, the typical temperatures are 635,664 and $700{ }^{\circ} \mathrm{C}$, respectively. Recent studies have shown that lizardite can present unusual behavior, with higher thermal stability and maximum temperatures between 715 and $720{ }^{\circ} \mathrm{C} .{ }^{20}$ When serpentine is heated beyond $650{ }^{\circ} \mathrm{C}$, different phases such as $\mathrm{SiO}_{2}$

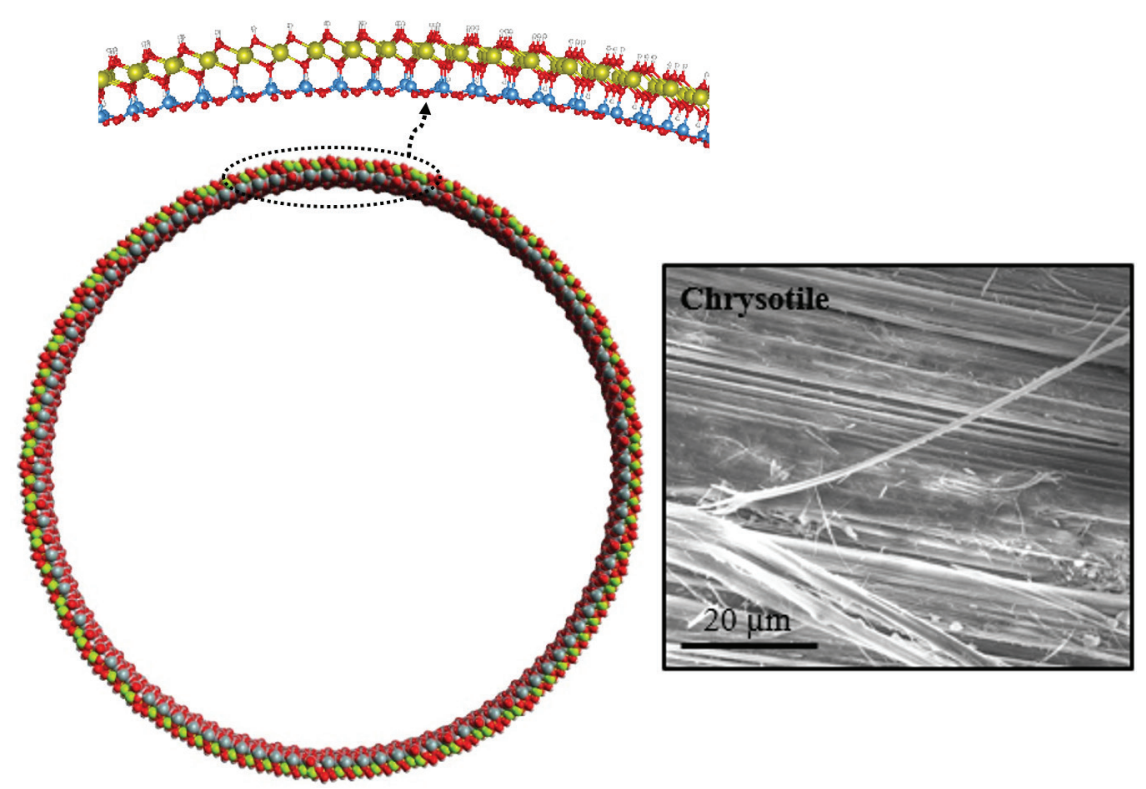

Figure 4. Chrysotile: concentric structure and scanning electron microscopy (SEM) image. 


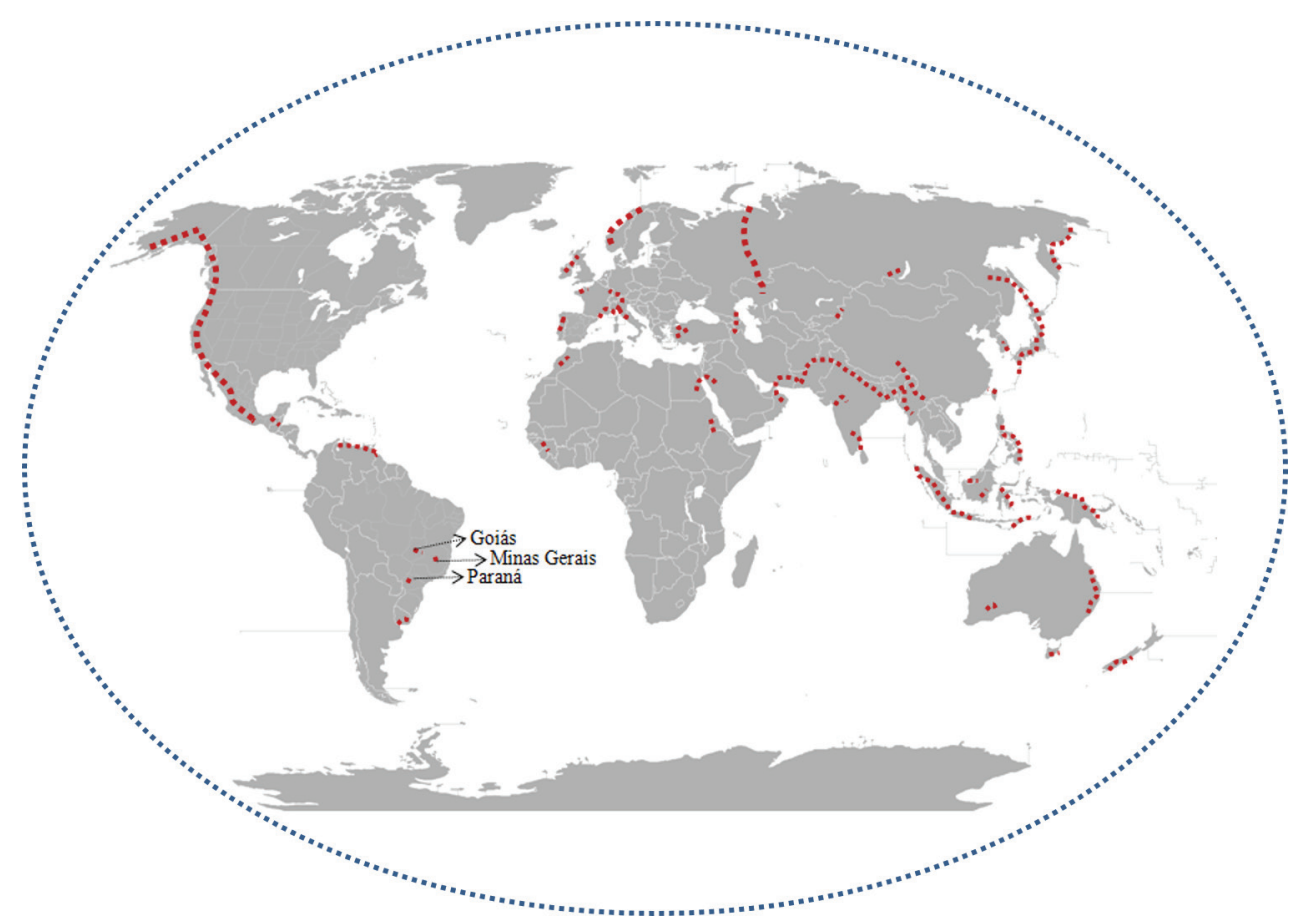

Figure 5. Serpentinite main reserves in the world (adapted from reference 11).

(cristobalite), $\mathrm{Mg}_{2} \mathrm{SiO}_{4}$ (forsterite), and $\mathrm{Fe}_{0.3} \mathrm{Mg}_{0.7}\left(\mathrm{SiO}_{3}\right)$ (enstatite) are usually observed. ${ }^{21}$ The formation of these phases will depend on the position and proportion of the hydrated ortho-metasilicate anions (ortho- $\left[\mathrm{SiO}_{4}\right]^{4-}$ and meta- $\left.\left[\left(\mathrm{SiO}_{3}\right)^{2-}\right]_{\mathrm{n}}\right)$ originally involved in the serpentine formation process. ${ }^{12}$

\section{Applications of Serpentinite}

Serpentinite can be used in different areas due to its physical properties, the presence of relatively high concentrations of $\mathrm{Mg}$ and $\mathrm{Si}$, surface characteristics, among others. ${ }^{22}$ Some of these applications are shown in Figure 6 and described below.

\subsection{Construction and ceramics}

Serpentinites have been largely used as raw material for the production of ceramics. ${ }^{23-25}$ Some of the studies address the use of serpentinite tailings from mineral processing. ${ }^{22,23}$ The use of serpentinites in ceramics and civil construction (Figure 7) is mainly due to its mechanical properties and also to its dark green color. Serpentinite has also been used as a thermal and electrical insulator in industrial applications. ${ }^{26}$

The ceramic industry stands out due to the possibility of recycling the waste from the companies processing this mineral, since it has a high volume of production, which allows the consumption of large quantities of tailings and, together with the physicochemical characteristics of the ceramic raw materials and the particularities of ceramic processing, makes this sector one of the great options for the processing of this mineral. ${ }^{22,27}$

\subsection{Application in agriculture}

Serpentinites have several interesting features for application in agriculture and may be used as a source of magnesium, silica and micronutrients, e.g., Ni, Cr. This material can also be used to increase the $\mathrm{pH}$ of typical acidic Brazilian soils due to the presence of brucite $(\mathrm{Mg}$ hydroxide layer).

Serpentinite has been tested as Mg source fertilizer in combination with nitrogen, phosphorus, and potassium. According to Błońska et al. ${ }^{28,29}$ soils enriched with serpentinite showed high magnesium content. This reduced the molar amount of exchangeable calcium with magnesium, which improved significantly the absorption of this mineral by the roots of the trees. ${ }^{28,29}$ It was also demonstrated that serpentinite participates strongly as fertilizer being as an important $\mathrm{Mg}$ source. ${ }^{30}$

\subsection{Source of silica and magnesium}

Serpentinite contains $32-38 \% \mathrm{MgO}$ and $35-40 \% \mathrm{SiO}_{2}$ and can be a source for these oxides. ${ }^{31}$ Pure magnesium compounds can be produced from serpentinite through acid leaching (equation 3). 


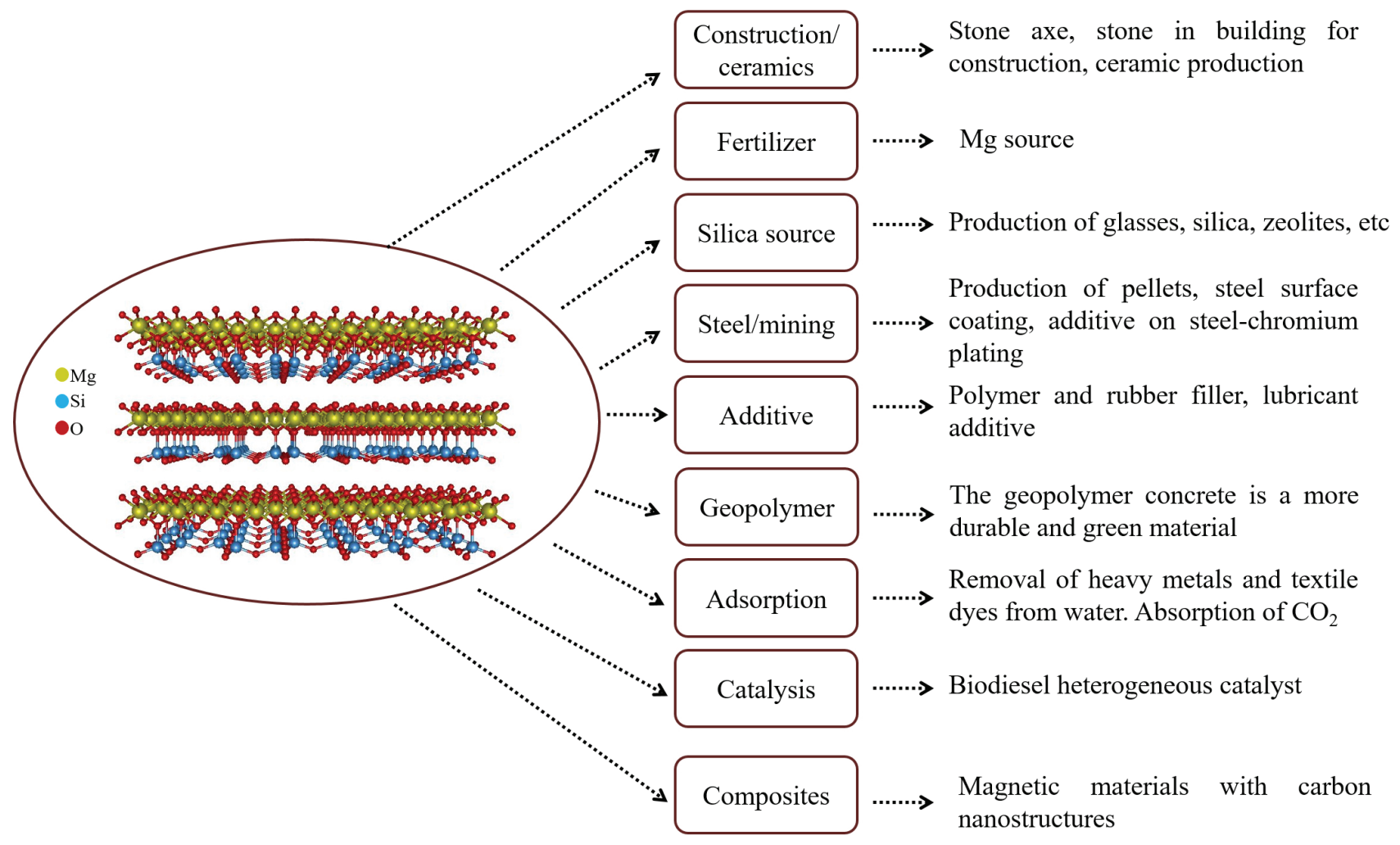

Figure 6. Potential applications for serpentinite-based materials.
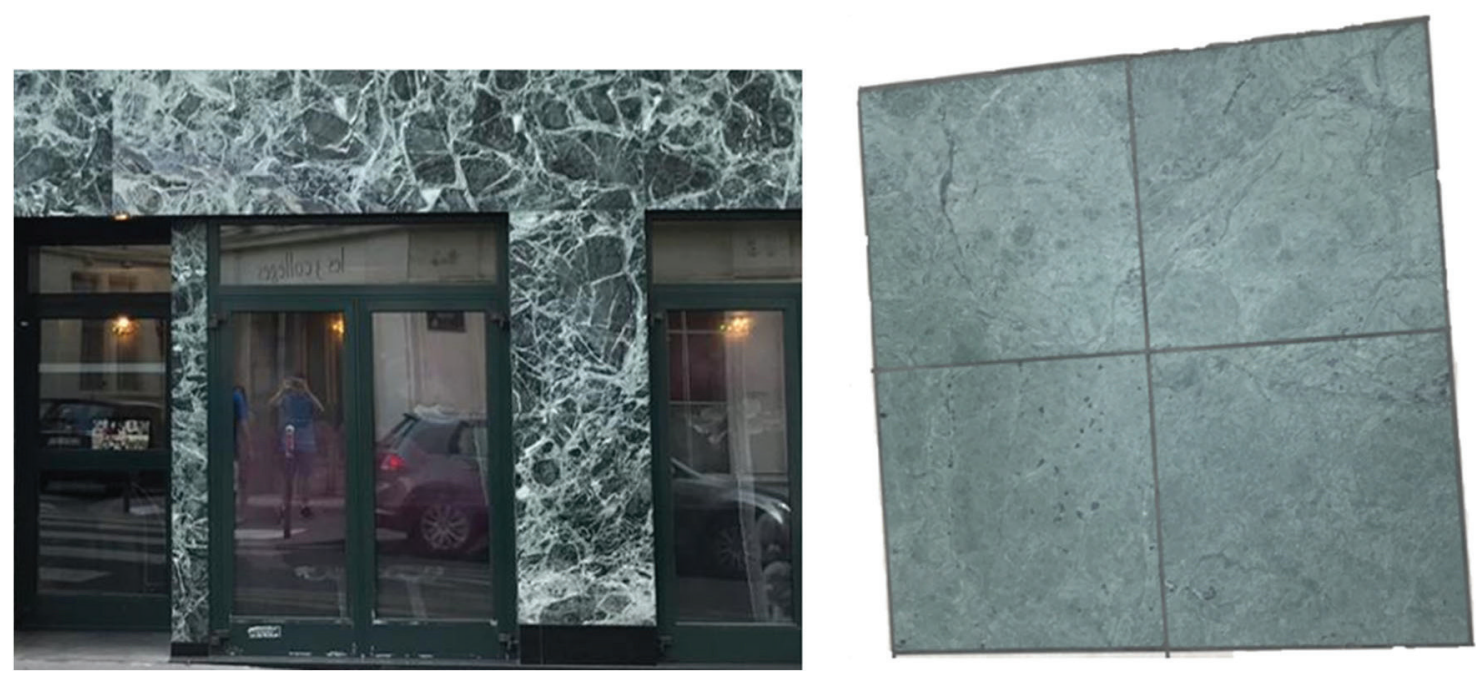

Figure 7. Use of serpentinite as a decorative stone in construction (photograph taken by the author in Italy).

$\mathrm{Mg}_{3} \mathrm{Si}_{2} \mathrm{O}_{5}(\mathrm{OH})_{4(\mathrm{~s})}+6 \mathrm{H}_{(\text {aq) }}^{+} \rightarrow 3 \mathrm{Mg}^{2+}{ }_{(\mathrm{qq})}+2 \mathrm{SiO}_{2(\mathrm{~s})}+5 \mathrm{H}_{2} \mathrm{O}_{(\mathrm{l})}$

The leaching generates a soluble magnesium salt, which accumulates in solution and can be separated from the insoluble residue and further refined. ${ }^{4,32}$ The most used leaching agent is hydrochloric acid, however, other inorganic and organic acids can be used. The products $\mathrm{SiO}_{2}$ and $\mathrm{Mg}^{2+}$ salts have different applications, as illustrated in Figure 8.
Among the main applications of magnesium hydroxide, sugar refining is mentioned, as well as industrial production of paper and cellulose and uranium processing. In plastic and foam industry, magnesium hydroxide acts as a flame retardant, being used to minimize the possibility of combustion and the flame spread in plastic materials. Magnesium hydroxide may further be used as a precipitating agent in the treatment of effluents for removal of heavy metal ions. ${ }^{33}$ 


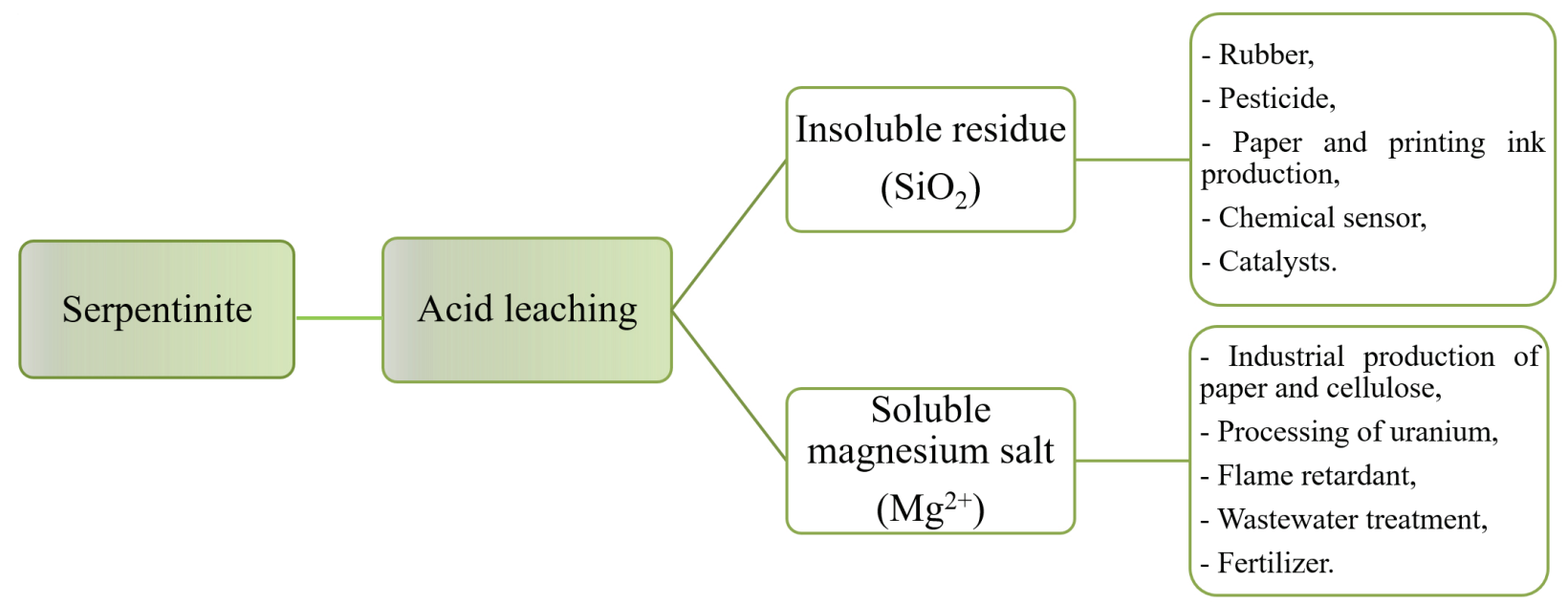

Figure 8. Magnesium and silica production from serpentinite and some applications of the $\mathrm{SiO}_{2}$ and $\mathrm{Mg}^{2+}$ salts. ${ }^{4,32}$

Sirota et al..$^{34}$ produced crystalline $\mathrm{Mg}(\mathrm{OH})_{2}$ through the treatment of the serpentinite with nitric acid at temperatures close to $80{ }^{\circ} \mathrm{C}$. The precipitation of $\operatorname{Mg}(\mathrm{OH})_{2}$ occurred from the addition of concentrated ammonium hydroxide.

Faster dissolution of magnesium can be obtained if serpentinite is calcined prior to the leaching step. Moreover, the use of calcined serpentinite may reduce problems related to reactor corrosion as solutions of weak acids or hydrolyzing salts and lower temperatures and leaching pressures could be used. ${ }^{4,16,35,36}$

The calcination temperature and time have an important effect on the amount of magnesium dissolved during the leaching step (with $\mathrm{HCl}$ ) of the calcined serpentinite. ${ }^{4,16,35}$ Thermal treatment of this mineral at temperatures ranging from $600-700{ }^{\circ} \mathrm{C}$ made the material more reactive. The percentage of dissolved magnesium was 30 times greater for the heat-treated serpentinite.

The serpentinite can also be an excellent source of amorphous silica, obtained from its thermal decomposition. Amorphous silica can be used in several industrial sectors, including the reinforcement of elastomer products like tires, rubber goods, and drug delivery systems; rubber production, pesticides, paper, catalyst support, and chemical sensors. ${ }^{32}$ The serpentinite can be used as a source of silica as reported by Fedoročková et al. ${ }^{4}$

Silica is the insoluble residue of the acidic dissolution of this rock. Serpentinite with high lizardite content, obtained from a mining industry residue, was used to produce amorphous silica with high purity. The influence of parameters such as granulometry, $\mathrm{HCl}$ concentration, temperature, and mass/volume ratio in the leaching process was evaluated by Arce et al. ${ }^{37}$ Serpentinite with relatively low $\mathrm{Al}^{3+}, \mathrm{Fe}^{3+}$ and $\mathrm{Fe}^{2+}$ contents reduce the formation of hydrated silica and improve the dissolution of the mineral. Results indicated that in samples larger than $300 \mathrm{~mm}$, the extractions of magnesium and iron were more efficient. The appropriate particle size will be a function of the material chemical characteristics, mainly its mineralogical complexity and crystal chemistry.

Among the numerous applications of $\mathrm{SiO}_{2}$, their use for the production of zeolites and mesoporous silicas can be highlighted. ${ }^{38}$ These materials have numerous applications, especially in the petroleum industry, which uses them as catalysts for the cracking of petroleum. ${ }^{39}$ In addition, the modification of silica also allows the production of compounds of greater versatility and with specific properties related to the species linked to its surface. ${ }^{40,41}$ The possibility of using a natural source like serpentinite to obtain silica gel which can then be chemically modified to produce an inorganic-organic hybrid may be interesting given the various opportunities these materials can offer.

\subsection{Steel/mining}

Serpentinite is used in the steelmaking process as $\mathrm{MgO}$-bearing flux agent. ${ }^{42} \mathrm{In}$ this process, the $\mathrm{MgO}$ combines with impurities in the molten steel to form the slag. This coproduct slag can be used in different applications such as road surfacing, concrete aggregate and embankment fill. ${ }^{43}$

\subsection{Additives}

Serpentinite can be used as a lubricating oil additive at $400{ }^{\circ} \mathrm{C}$ to produce a $\mathrm{Si}$-based protective layer. ${ }^{44}$ Experimental data shows that the additive takes part in the formation of the self-repairing film. Isomorphic replacement between $\mathrm{Fe} / \mathrm{Cr}$ and the serpentinite occurred, which was the essence of the tribochemical reaction during the metal wear process of self-repair. 


\subsection{Filler for polymers}

Serpentinite can be used as filler in polypropylene composites $^{45}$ leading to important improvements in the mechanical and thermochemical stability of the composites. It also may be used in high and low-density polyethylene. ${ }^{46}$ The presence of serpentinite at 20-40 wt.\% led to a substantial increase in different mechanical properties of polyethylene. Most of these studies used very fine tailings considered a waste in serpentinite mine.

\subsection{Adsorption of metals}

The surface of the serpentinite mineral contains a large amount of water surface $-\mathrm{OH}$ groups. These groups are responsible for the properties associated with high adsorption capacity that is directly related to surface charge and $\mathrm{pH}$.

The point of zero charges (PZC) of serpentine is ca. 4.3. ${ }^{47,48}$ According to Pollastri et al ${ }^{49}$ in minerals of this type, charges can arise due to a surface exposure that occurs because of the breaking of hydrogen bonds that bind the tetrahedral-octahedral units. These two exposed surfaces are formed of oxygen atoms and protons that saturate the other surface that is negative. Acid-base characteristics of serpentine in water can be ascribed to the acidic silicate layers and the basic brucite-like layers. In the high $\mathrm{pH}$ range, serpentine is stable and hydroxyls at the surface of the fiber determine an overall negative zeta potential of the particle. According to Momcilovic et al. ${ }^{48}$ in water, the serpentinite surface has a high concentration of $\mathrm{OH}$ groups, which can resist the surface charge and is $\mathrm{pH}$ dependent. A simplified representation of charge generation on the serpentine surface is shown in Figure 9.

The adsorption of $\mathrm{Cd}^{2+}\left(\mathrm{CaO}\right.$ et al $\left.^{15}\right)$ was investigated on serpentinite, showing values of $7.7 \mathrm{mg} \mathrm{g}^{-1}$. After thermal activation, the adsorption capacity increased significantly, reaching $15.2 \mathrm{mg} \mathrm{g}^{-1}$. The $\mathrm{Cd}^{2+}$ adsorption in both cases was discussed in terms of electrostatic interaction with a negative charge on surface oxygen.

Serpentinite can also be used in the removal of hexavalent chromium. This ion is usually present in industrial wastewaters such as the ones originated from electroplating, pigment, chrome plating, leather tanning, and metal finishing. Hexavalent chromium shows two main forms, i.e., chromate $\left(\mathrm{CrO}_{4}{ }^{2-}\right)$ and dichromate $\left(\mathrm{Cr}_{2} \mathrm{O}_{7}{ }^{2-}\right)$; both forms are highly toxic in nature. ${ }^{50}$ According to Mpouras et al. $^{51}$ chromium removal might be related to two main effects: adsorption and reduction. A reduction of approximately $50 \%$ was observed at $\mathrm{pH} 5$. Between pH 3-7 the adsorption was constant. These two mechanisms of removal of the contaminant occur on the surface of the mineral. Reduction is directly influenced by the adsorption since $\mathrm{Cr}^{6+}$ must be adsorbed on the surface for reduction to occur. Serpentinite has also been suggested as a selective adsorbent for the removal of copper $\left(\mathrm{Cu}^{2+}\right)$ present in solution with other metals such as $\mathrm{Ni}^{2+}, \mathrm{Mn}^{2+}, \mathrm{Zn}^{2+}$, and $\mathrm{Cd}^{2+} \cdot 52$

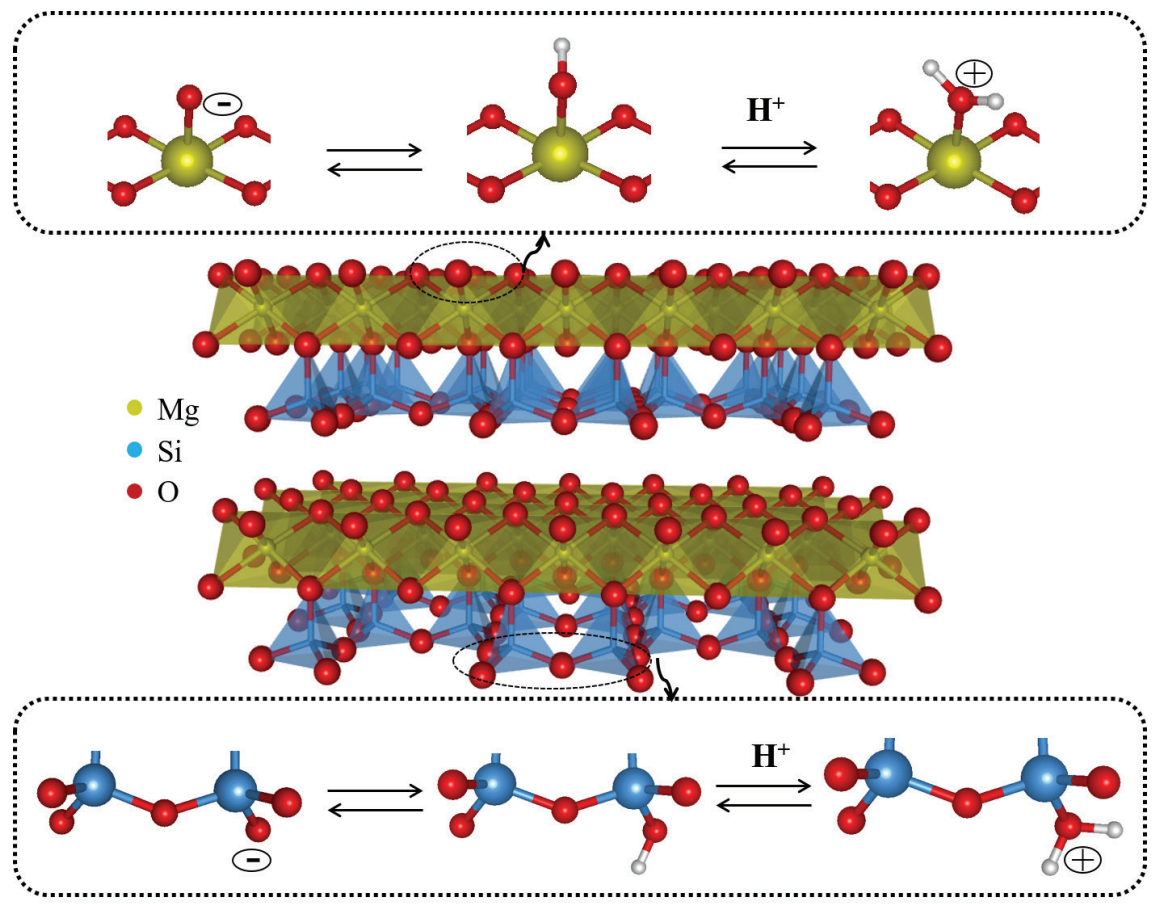

Figure 9. Development of surface charges on serpentine. 


\subsection{Adsorption of organics}

Dye adsorption by serpentinite has also been studied, as described by Shaban et al. ${ }^{50}$ The dye removal process was suggested to involve only chemical adsorption. Kinetic models were utilized to investigate the adsorption mechanism of Cong red dye and methylene blue on serpentine. The kinetic model of pseudo $2^{\text {nd }}$ order indicates that the adsorption mechanism is of the chemisorption type and that it occurs through cationic exchange. Removal of the cationic dye (methylene blue) was superior to the adsorption capacity of the anionic dye (Congo red). This may indicate that surface loads influence on the removal process. Generally, as already presented, these minerals present negative charge and, therefore, a greater affinity for cationic pollutants. ${ }^{50}$

The adsorption of anionic dyes (Procion red MX-5B, Procion orange, and Ramazol black) was also evaluated by Momcilovic et al. ${ }^{48}$ Removal rates above $98 \%$ were achieved; nevertheless, relatively high adsorbent dosages were needed for removal of anionic dyes.

\subsection{Absorption/capture of $\mathrm{CO}_{2}$}

Carbon dioxide sequestration by serpentinites has been evaluated by several researchers from all over the world. ${ }^{53-57}$ Direct carbonation involving serpentinite and forsterite rocks has been proposed. ${ }^{58-61}$ In this case, the $\mathrm{CO}_{2}$ is dissolved in solution forming carbonic acid. This causes a $\mathrm{pH}$ reduction in the medium, allowing the dissolution of the magnesium silicate and the subsequent carbonation. ${ }^{62}$ This process can be summarized in two stages: dissolution of $\mathrm{Mg}^{2+}$ in acidic $\mathrm{pH}$, followed by precipitation of magnesium carbonate in basic $\mathrm{pH}$ (equations 4 and 5). However, very low efficiencies have been observed. ${ }^{63}$

$$
\begin{aligned}
& \mathrm{Mg}_{3} \mathrm{Si}_{2} \mathrm{O}_{5}(\mathrm{OH})_{4(\mathrm{~s})}+3 \mathrm{CO}_{2(\mathrm{~g})} \rightarrow 3 \mathrm{MgCO}_{3(\mathrm{~s})}+2 \mathrm{SiO}_{2(\mathrm{~s})}+ \\
& 2 \mathrm{H}_{2} \mathrm{O}_{(\mathrm{l})}+64 \mathrm{~kJ} \mathrm{~mol}^{-1}
\end{aligned}
$$

$2 \mathrm{Mg}_{2} \mathrm{SiO}_{4(\mathrm{~s})}+2 \mathrm{CO}_{2(\mathrm{~g})} \rightarrow 2 \mathrm{MgCO}_{3(\mathrm{~s})}+\mathrm{SiO}_{2(\mathrm{~s})}+$ $90 \mathrm{~kJ} \mathrm{~mol}^{-1}$
Two alternative routes for $\mathrm{CO}_{2}$ sequestration by serpentinites have been investigated: using the $\mathrm{Mg}^{2+}$ to form carbonate ${ }^{58,64}$ and using the silicate with another metal, e.g., $\mathrm{Li}^{+},{ }^{19}$ as shown schematically in Figure 10.

Producing free $\mathrm{MgO}$ or $\mathrm{Mg}(\mathrm{OH})_{2}$ from serpentine is a first step in magnesium silicate carbonation. ${ }^{58,65,66}$ For serpentine, this implies the following chemistry (equations 6 and 7):

$\mathrm{Mg}_{3} \mathrm{Si}_{2} \mathrm{O}_{5}(\mathrm{OH})_{4(\mathrm{~s})} \rightarrow 3 \mathrm{MgO}_{(\mathrm{s})}+2 \mathrm{SiO}_{2(\mathrm{~s})}+2 \mathrm{H}_{2} \mathrm{O}_{(\mathrm{l})}$

$\mathrm{Mg}_{3} \mathrm{Si}_{2} \mathrm{O}_{5}(\mathrm{OH})_{4(\mathrm{~s})}+2 \mathrm{H}_{2} \mathrm{O}_{(\mathrm{l})} \rightarrow 3 \mathrm{Mg}(\mathrm{OH})_{2(\mathrm{~s})}+2 \mathrm{SiO}_{2(\mathrm{~s})}$

Recently, a lithium silicate capable of capturing $\mathrm{CO}_{2}$, obtained from the reaction between serpentinite and lithium hydroxide, has been described (equations 8 and 9).

$$
\begin{aligned}
& \mathrm{Mg}_{3} \mathrm{Si}_{2} \mathrm{O}_{5}(\mathrm{OH})_{4}+8 \mathrm{LiOH} \rightarrow 2 \mathrm{Li}_{4} \mathrm{SiO}_{4}+3 \mathrm{MgO}+6 \mathrm{H}_{2} \mathrm{O} \\
& \mathrm{Li}_{4} \mathrm{SiO}_{4}+2 \mathrm{MgO}+2 \mathrm{CO}_{2} \rightleftharpoons \mathrm{Li}_{2} \mathrm{MgSiO}_{4}+\mathrm{Li}_{2} \mathrm{CO}_{3}+ \\
& \mathrm{MgCO}_{3}
\end{aligned}
$$

The intercalation of lithium in the serpentine minerals generates $\mathrm{Li}_{4} \mathrm{SiO}_{4}$ and $\mathrm{MgO}$ as main phase (equation 8). These phases are considered potentially $\mathrm{CO}_{2}$ capture agents because of their high thermal stability and selectivity. Data obtained previously shows that this material can capture approximately $25 \%$ by mass of $\mathrm{CO}_{2}$ in a dynamic cycle and can reach up to $36 \%$ at $500{ }^{\circ} \mathrm{C}$ (equation 9). The stability of this material was also evaluated during cycles of use and results show a loss of only $6 \%$ of its efficiency. ${ }^{19}$

A two-step carbonation has been proposed, in which stage 1 is related to the surface reaction with $\mathrm{CO}_{2}$ to form a carbonate layer and stage 2 is where the $\mathrm{Li}^{+}$diffusion controls the reaction. ${ }^{19}$

\subsection{Catalysis}

Serpentinite has not been used directly as a catalyst but has shown very interesting results as precursor to producing active catalysts. The layered structure of serpentine allows

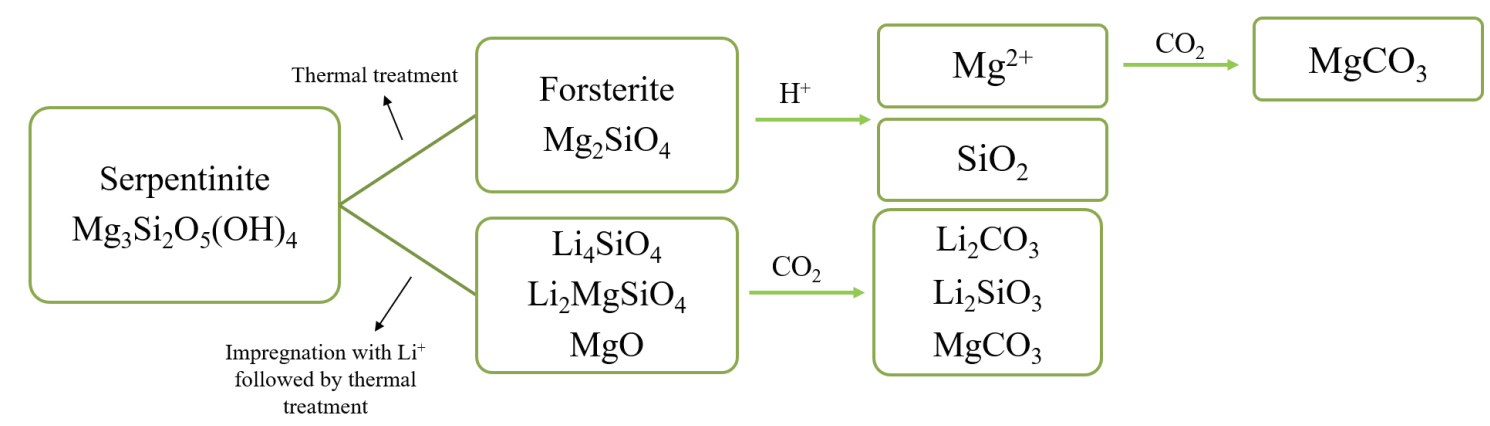

Figure 10. Possible pathways of $\mathrm{CO}_{2}$ capture by serpentinites. 


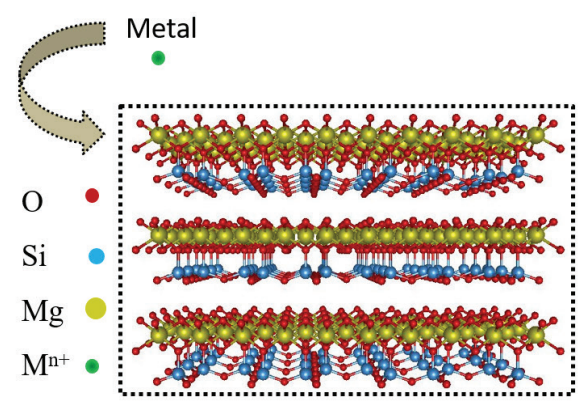

Serpentinite

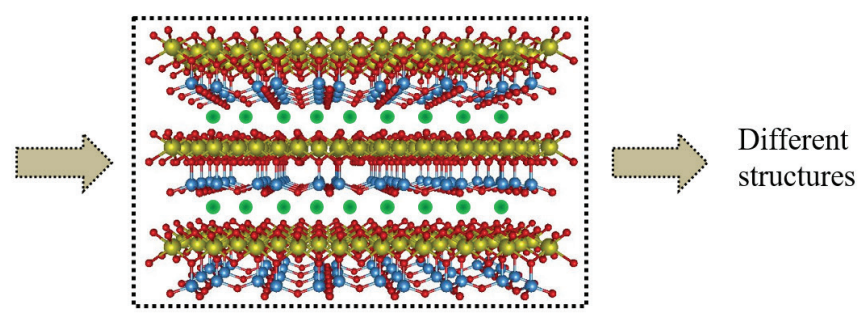

Intercalation of $\mathrm{M}^{\mathrm{n}+}$

Figure 11. Diffusion of metal cations into serpentine interlayer space followed by dehydration to form MSiMg oxides (adapted from reference 18).

the diffusion of different cations in the interlamellar space, which is followed by a reaction in the solid state that produces different phases of silicon oxide and magnesium. The intercalation of metal cations in such structures is thus a potential versatile route for preparing $\mathrm{M}_{\mathrm{a}} \mathrm{Mg}_{\mathrm{b}} \mathrm{Si}_{\mathrm{c}} \mathrm{O}_{\mathrm{d}}$ oxides which can be used in various technological applications (Figure 11).

The intercalation of serpentine with the alkaline metals $\mathrm{K}^{+19}$ and $\mathrm{Na}^{+18}$ produced the $\mathrm{K}_{2} \mathrm{MgSiO}_{4}$ and $\mathrm{Na}_{2} \mathrm{Mg}_{2} \mathrm{Si}_{2} \mathrm{O}_{7}$ silicates, active as basic catalysts for the production of biodiesel. The catalytic site of phase $\mathrm{Na}_{2} \mathrm{Mg}_{2} \mathrm{Si}_{2} \mathrm{O}_{7}$ is discussed in terms of a Na+ interaction with a $\mathrm{Si}_{2} \mathrm{O}_{7}$ moiety to form the basic species $\mathrm{Si}-\mathrm{O}-\mathrm{Na}^{+}{ }^{18}$

Just like the serpentine structure formed basically by antigorite and lizardite, materials constituted by the chrysotile polymorph can also be used for various purposes. The combination of chrysotile fibers with $\mathrm{KOH}$ to produce basic catalysts has also been evaluated. The impregnation of $\mathrm{K}^{+}$serpentinite followed by heat treatment at $700{ }^{\circ} \mathrm{C}$ produced sintered particles containing phases of $\mathrm{MgO}$ doped with $\mathrm{K}^{+}$catalytically active for the transesterification of soybean oil with methanol. ${ }^{67,68}$

\subsection{Composites}

Serpentinites have also been used as a precursor and catalyst support to produce magnetic amphiphilic composites by chemical vapor deposition (CVD). ${ }^{68-71}$

In these works, $\mathrm{Fe}$ or Co were impregnated on the serpentinite surface followed by a CVD using methane or ethanol, a carbon source to grow carbon nanotubes and nanofibers. ${ }^{68,70}$ The resulting composites showed very interesting features, such as magnetic properties due to the Fe metal nuclei inside carbon structures and an amphiphilic character due to the carbon hydrophobic surface combined with the MgSi oxide hydrophilic surface. These composites showed good results as magnetic adsorbents for the hormone ethinylestradiol. ${ }^{69}$ After adsorption, the particles can be easily removed by a simple magnetic separation process. These composites using chrysotile were conformed as threads, screens, and pellets to produce different filtering media. ${ }^{68-71}$

Due to their amphiphilic character, these composites showed the unique property of forming and breaking oil/ water emulsions. ${ }^{68}$ One application studied using this emulsion breaking property was the treatment of biodiesel wastewaters to remove the oil dispersed. ${ }^{71}$ These amphiphilic composites were also used to adsorb and oxidize dyes such as methylene blue by a Fenton mechanism. ${ }^{70}$

Another interesting application of serpentinite is the synthesis of electrodes. Electrochemistry of carbon paste electrode, which contained serpentinite powder and graphite, was examined in an electrode cell regarding its electrocatalytic and sensing properties. The results indicate that the hydroxyls of the minerals structure are responsible for the main interactions between them and the solution electroactive species, responsible for electronic transfers. The serpentinite-modified electrode obtained a better voltammetric response. There was an amplification of the current and the electroactive surface area in addition to a reduction of the separation of the peaks. This suggests that electron transfer is occurring faster. ${ }^{72}$ The work of Momcilovic et al. ${ }^{48}$ also indicates that, due to its structure, surface groups, morphology, and composition, serpentinite and forsterite exhibited good electrocatalytic activity.

\subsection{Asbestos-containing chrysotile}

Chrysotile also belongs to the serpentinite family and can usually be found in very small harmless amounts, mixed with lizardite and antigorite. It has also been extracted from many mining in the world for different applications. Asbestos minerals containing chrysotile presented industrial applications spread between the $19^{\text {th }}$ and $20^{\text {th }}$ centuries due to some physical properties such as flame resistance, high tensile strength, thermal insulation, resistance to chemical and biological agents. The term asbestos is a generic term that comprises some natural minerals represented by hydrated silicates which are easily 
separable into thin and flexible fibers. ${ }^{73,74}$ Asbestos is the common name used for two families of fibrous minerals that differ in crystal and chemical characteristics: serpentine (i.e., chrysotile) and amphiboles (i.e., crocidolite, amosite, anthophyllite, actinolite, and tremolite). ${ }^{75}$ The use of asbestos was prohibited in several countries, ${ }^{75}$ mainly after verification of the health risk related to extraction and production. Exposure to asbestos has mutagenic effects, inducing some asbestos-related diseases, especially malignant mesothelioma. ${ }^{73,74}$ The most dangerous fibers are those having a diameter of $0-1 \mu \mathrm{m}$ and a length of 5-10 $\mu \mathrm{m}$ with small solubility. Asbestos fits the latter type of fiber, so its use is banned worldwide. ${ }^{76,77}$ Several recent articles in literatures have discussed these points. ${ }^{78-80}$

\section{Conclusion and Challenges for Future Research}

Minerals of the serpentine family have very interesting physicochemical properties and a great potential for different technological applications. Despite this potential, relatively few studies have been carried out. Due to the existence of large reserves in Brazil, new applications for serpentinites can offer important opportunities.

Still, several aspects and challenges for future research on serpentine potential applications must be addressed. One important issue is the use of tailings of serpentinite mining, which are based on a fine powder with no current use. Some of the potential applications of this fine tailing powder are its use as a polymer filler and the production of catalyst and adsorbent. In adsorption, more complex and dangerous organic molecules such as hormones, antibiotic and other emerging contaminants could be investigated. Another important aspect of serpentinite investigation is its structural modification to increase $\mathrm{Mg}$ availability for agriculture and also adsorption of nutrients, ex phosphate and zinc to produce a new application in agriculture. More efficient processes to separate $\mathrm{MgO}$ and $\mathrm{SiO}_{2}$, concerning cost and environmental impact, are considerably important. Another current trend is the use of serpentinite to obtain silica for geopolymers. As serpentinite has an important use in the steel industry, new applications of the serpentinitebased slag waste produced is important. Since serpentines allow the synthesis at relatively mild conditions of different MMgSi oxides, the synthesis and application of these materials can open new and exciting areas. Due to the basic properties of these oxides, different applications in alkaline catalysis can be envisioned, as well as $\mathrm{CO}_{2}$ capture and adsorption. Another important aspect to be considered for serpentinite use is the presence of the harmful chrysotile asbestos fibers, being an important occupational concern.

\section{Acknowledgments}

The authors acknowledge Pedras Congonhas Ltda, the UFMG Microscopy Center for the images and the support of CNPQ, INCT Midas, CAPES and FAPEMIG.

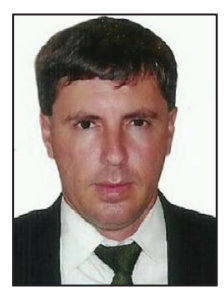

Ottavio Raul D. R. Carmignano is graduated in Law at Faculdade Milton Campos (MG-Brazil, 1996) and Masters in Socioeconomic Environmental Sustainability by the Federal University of Ouro Preto (UFOP, MG-Brazil, 2015). He is Manager Partner at Pedras Congonhas Ltda, since 1992. He researches new applications for serpentinite rock in industrial markets. Currently he is a PhD student in innovation at Federal University of Minas Gerais (UFMG, MG-Brazil).

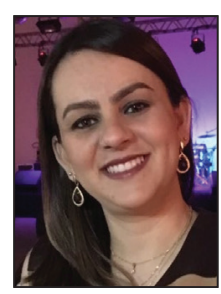

Sara S. Vieira is graduated in Chemistry from the Federal University of Lavras (UFLA, MG-Brasil-2009). She obtained her master's and doctoral degree (2014) also by UFLA in the postgraduate program in Agrochemistry with Sandwich period in the Center of Structural Chemistry of Instituto Superior Técnico (IST) of the University of Lisbon (2013). She held postdoctoral degrees at UNIFAL-MG and at the Chemistry Department at UFMG. Since 2010 she has focused her research on the evaluation of potential adsorbents and catalysts based on mesoporous silicates, iron oxides and mining residues. Her studies mainly evaluated the applicability of these materials as catalysts for the production of biofuel and products of greater added value.

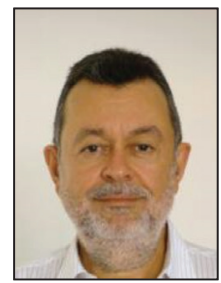

Paulo Roberto G. Brandão is Mining Engineer, Federal University of Minas Gerais, Brazil, 1968; Masters and PhD, University of British Columbia, Vancouver, Canada, 1982. Research Engineer and Research Supervisor, Magnesita Group (Brazil) during 15 years. Full Professor, Federal University of Minas Gerais, Brazil, Department of Mining Engineering. He retired in 2003 and was awarded the title of Professor Emeritus. Areas of interest: ores and industrial minerals characterization and processing; reagents for minerals processing; recycling of mineral wastes, aggregation and dispersion of mineral slurries; ironmaking, ceramics and refractories. He has supervised 40 completed master's 
theses and 24 completed doctoral theses; is co-author of circa 200 published papers in international refereed journals and in conference proceedings.

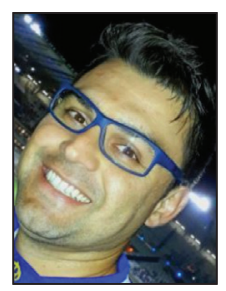

Alexandre C. Bertoli is graduated in Chemistry from the University Center of Lavras (2009). He obtained his master's and doctoral degree by UFLA (2014) in the postgraduate program in Agrochemistry with Sandwich period in the Center of Structural Chemistry of Instituto Superior Técnico (IST) of the University of Lisbon (2013). He held postdoctoral degrees at UNIFAL-MG and at the Chemistry Department at UFMG. His researches are related to the mobility of trace metals in environmental/ biological systems and molecular modeling applied to coordination compounds. His studies mainly evaluated the chemical speciation and mechanism of retention/ complexation of heavy metals.

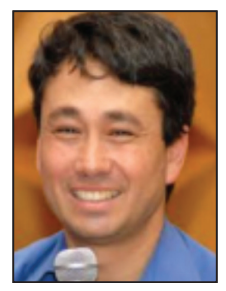

Rochel M. Lago is graduated at Universidade de Campinas (UNICAMP, São Paulo State, Brazil) with MSc under the supervision of Prof Ulf Schuchardt. In 1992, he spent one year at Gifu University (Japan) followed by a PhD at Oxford University (United Kingdom) under the supervision of Prof M. L. H. Green and a Post-Doc with Prof J. L. G Fierro at Institute of Catalysis and Petrochemistry (Madrid, Spain) working always in the area of catalysis. In 2005, he went to University of Montreal (Canada) as a Visiting Researcher at the laboratories of Prof Richard Martel to work with carbon nanotubes and a Post-Doc at the business school HEC (Heutes Etudes Commerciales, Canada) with Prof L. J. Filion on the theme of technological entrepreneurship. He works at Department of Chemistry at Universidade Federal de Minas Gerais (UFMG, Minas Gerais State, Brazil) since 1997.

\section{References}

1. Rakovan, J.; Rocks Miner. 2011, 98, 63.

2. Evans, B. W.; Hattori, K.; Baronnet, A.; Elements 2013, 9 , 99.

3. Guillot, S.; Schwartz, S.; Reynard, B.; Agard, P.; Prigent, C.; Tectonophysics 2015, 646, 1.

4. Fedoročková, A.; Plešingerová, B.; Sučik, G.; Raschman, P.; Doráková, A.; Int. J. Miner. Process. 2014, 130, 42.

5. Hršak, D.; Sučik, G.; Lazić, L.; Metalurgija 2008, 47, 29.

6. Zhou, S.; Wei, Y.; Li, B.; Ma, B.; Wang, C.; Wang, H.; J. Alloys Compd. 2017, 713, 180.
7. Pellant, C.; Rocks \& Minerals; Dorling Kindersley Publishers Ltd.: London, 1992.

8. Lourenço, M. P.; de Oliveira, C.; Oliveira, A. F.; Guimarães, L.; Duarte, H. A.; J. Phys. Chem. C 2012, 116, 9405.

9. Demichelis, R.; de La Pierre, M.; Mookherjee, M.; ZicovichWilson, C. M.; Orlando, R.; CrystEngComm 2016, 18, 4412.

10. da Luz, A. B.; Lins, F. A. F.; Rochas \& Minerais Industriais; CETEM/MCT: Rio de Janeiro, 2005.

11. del Real, P.; Vishal, V. In Geologic Carbon Sequestration: Understanding Reservoir Behavior; Vishal, V.; Singh, T. N., eds.; Springer International Publishing: Cham, 2016, p. 213.

12. Zulumyan, N.; Isahakyan, A.; Beglaryan, H.; Melikyan, S.; J. Therm. Anal. Calorim. 2018, 131, 1201.

13. Machado, F. M.; Pereira, A. G. In Sumário Mineral; Lima, T. M.; Neves, C. A. R., eds; Departamento Nacional de Produção Mineral: Brasília, 2010 apud Rezende, M. M. In Sumário Mineral; Lima, T. M.; Neves, C. A. R., eds.; Departamento Nacional de Produção Mineral: Brasília, 2014.

14. Alves, N.; Xavier, C.; Dullius, J.; Ligabue, R.; Ketzer, J. M.; Seferin, M.; Einloft, S.; Quim. Nova 2013, 36, 773.

15. Cao, C.-Y. Y.; Liang, C.-H. H.; Yin, Y.; Du, L.-Y. Y.; J. Hazard. Mater. 2017, 329, 222.

16. Raschman, P.; Fedoročková, A.; Sučik, G.; Hydrometallurgy 2013, 139, 149.

17. Ballotin, F. C.; Cibaka, T. E.; Ribeiro-Santos, T. A.; Santos, E. M.; Teixeira, A. P. C.; Lago, R. M.; J. Mol. Catal. A: Chem. 2016, 422, 258.

18. Paz, G. M.; Vieira, S. S.; Bertoli, A. C.; Ballotin, F. C.; de Moura, E. M.; Teixeira, A. P. C.; Costa, D. A. S.; Carmignano, O.; Lago, R. M.; J. Braz. Chem. Soc. 2018, 29, 1823.

19. Vieira, S. S.; Paz, G. M.; Teixeira, A. P. C.; Moura, E. M.; Carmignano, O. R.; Sebastião, R. C. O.; Lago, R. M.; J. Environ. Chem. Eng. 2018, 6, 4189.

20. Dlugogorski, B. Z.; Balucan, R. D.; Renewable Sustainable Energy Rev. 2014, 31, 353.

21. Liu, M.; Gadikota, G.; Fuel 2018, 227, 379.

22. Cavallo, A.; Resour. Policy 2018, 59, 17.

23. Nemat, S.; Ramezani, A.; Emami, S. M.; Ceram. Int. 2016, 42, 18479.

24. Ramezani, A.; Emami, S. M.; Nemat, S.; Ceram. Int. 2018, 44, 9269.

25. Ramezani, A.; Emami, S. M.; Nemat, S.; J. Hazard. Mater. 2017, 338, 177.

26. Pereira, D.; Blanco, J. A.; Peinado, M.; J. Mater. Civ. Eng. 2013, $25,1563$.

27. Díaz, L. A.; Torrecillas, R.; J. Eur. Ceram. Soc. 2007, 27, 2341.

28. Błońska, E.; Januszek, K.; Małek, S.; Wanic, T.; Int. Agrophys. 2016, 30, 401.

29. Błońska, E.; Pająk, M.; Małek, S.; Januszek, K.; Commun. Soil Sci. Plant Anal. 2017, 48, 692. 
30. Ranawat, P.; Kumar, K. M.; Sharma, N. K.; Curr. Sci. 2009, 96, 843.

31. Yoo, K.; Kim, B.-S.; Kim, M.-S.; Lee, J.; Jeong, J.; Mater. Trans. 2009, 50, 1225.

32. Raza, N.; Raza, W.; Madeddu, S.; Agbe, H.; Kumar, R. V.; Kim, K.-H.; RSC Adv. 2018, 8, 32651.

33. Sain, M.; Park, S. H.; Suhara, F.; Law, S.; Polym. Degrad. Stab. 2004, 83, 363.

34. Sirota, V.; Selemenev, V.; Kovaleva, M.; Pavlenko, I.; Mamunin, K.; Dokalov, V.; Yapryntsev, M.; Int. J. Min. Sci. Technol. 2018, 28, 499.

35. Fedoročková, A.; Hreus, M.; Raschman, P.; Sučik, G.; Miner. Eng. 2012, 32, 1.

36. Sierra, C.; Chouinard, S.; Pasquier, L. C.; Mercier, G.; Blais, J. F.; Waste Biomass Valorization 2018, 9, 1921.

37. Arce, G. L. A. F.; Soares Neto, T. G.; Ávila, I.; Luna, C. M. R.; Carvalho, J. A.; J. Cleaner Prod. 2017, 141, 1324.

38. Zhang, J.; Li, X.; Liu, J.; Wang, C.; Catalysts 2018, 9, 13.

39. Blay, V.; Louis, B.; Miravalles, R.; Yokoi, T.; Peccatiello, K. A.; Clough, M.; Yilmaz, B.; ACS Catal. 2017, 7, 6542.

40. Morin-Crini, N.; Fourmentin, M.; Fourmentin, S.; Torri, G.; Crini, G.; Environ. Chem. Lett. 2018, 16, 1361.

41. Cashin, V. B.; Eldridge, D. S.; Yu, A.; Zhao, D.; Environ. Sci.: Water Res. Technol. 2018, 4, 110.

42. Carmignano, O. R. D. R.; Carvalho, C. F.; REM, Rev. Esc. Minas 2014, 67, 47

43. https://www.resourcesandgeoscience.nsw.gov.au/_data/assets/ pdf_file/0020/238205/Serpentine.pdf, accessed in August 2019.

44. Qi, X.; Jia, Z.; Chen, H.; Yang, Y.; Wu, Z.; Tribol. Trans. 2013, $56,516$.

45. Tan, S.; Tincer, T.; J. Appl. Polym. Sci. 2011, 121, 846.

46. Oréfice, R.; Boaventura, T. P.; Carmignano, O. R.; Tribst, P.; Plástico Industrial 2014, 191, p. 68. Available at http://www. arandanet.com.br/assets/revistas/pi/2014/julho/index.php, accessed in August 2019

47. Alvarez-Silva, M.; Uribe-Salas, A.; Mirnezami, M.; Finch, J. A.; Miner. Eng. 2010, 23, 383.

48. Momcilovic, M. Z.; Randelovic, M. S.; Purenovic, M. M.; Dordevic, J. S.; Onjia, A.; Matovic, B.; Sep. Purif. Technol. 2016, 163,72 .

49. Pollastri, S.; Gualtieri, A. F.; Gualtieri, M. L.; Hanuskova, M.; Cavallo, A.; Gaudino, G.; J. Hazard. Mater. 2014, 276, 469.

50. Shaban, M.; Abukhadra, M. R.; Khan, A. A. P.; Jibali, B. M.; J. Taiwan Inst. Chem. Eng. 2018, 82, 102.

51. Mpouras, T.; Chrysochoou, M.; Dermatas, D.; J. Contam. Hydrol. 2017, 197, 29.

52. Huang, P.; Li, Z.; Chen, M.; Hu, H.; Lei, Z.; Zhang, Q.; Yuan, W.; Appl. Clay Sci. 2017, 149, 1.

53. Park, A. H. A.; Fan, L. S.; Chem. Eng. Sci. 2004, 59, 5241.

54. Ferrufino, G. L. A. A.; Okamoto, S.; dos Santos, J. C.; de
Carvalho, J. A.; Avila, I.; Luna, C. M. R.; Neto, T. G. S.; J. $\mathrm{CO}_{2}$ Util. 2018, 24, 164.

55. Power, I. M.; Wilson, S. A.; Dipple, G. M.; Elements 2013, 9 , 115.

56. Romão, I. S.; Gando-Ferreira, L. M.; da Silva, M. M. V. G.; Zevenhoven, R.; Miner. Eng. 2016, 94, 104.

57. Arce, G. L. A. F.; Neto, T. G. S.; Ávila, I.; Luna, C. M. R.; dos Santos, J. C.; Carvalho, J. A.; Hydrometallurgy 2017, 169, 142.

58. Farhang, F.; Rayson, M.; Brent, G.; Hodgins, T.; Stockenhuber, M.; Kennedy, E.; Chem. Eng. J. 2017, 330, 1174.

59. Olajire, A. A.; J. Pet. Sci. Eng. 2013, 109, 364.

60. Werner, M.; Hariharan, S.; Mazzotti, M.; Phys. Chem. Chem. Phys. 2014, 16, 24978.

61. Pasquier, L.-C.; Mercier, G.; Blais, J.-F.; Cecchi, E.; Kentish, S.; Environ. Sci. Technol. 2014, 48, 5163.

62. Farhang, F.; Oliver, T. K.; Rayson, M.; Brent, G.; Stockenhuber, M.; Kennedy, E.; Chem. Eng. J. 2016, 303, 439.

63. Pasquier, L. C.; Mercier, G.; Blais, J. F.; Cecchi, E.; Kentish, S.; Appl. Geochem. 2014, 50, 66.

64. Oliver, T. K.; Farhang, F.; Hodgins, T. W.; Rayson, M. S.; Brent, G. F.; Molloy, T. S.; Stockenhuber, M.; Kennedy, E. M.; Energy Fuels 2019, 33, 1753.

65. Nduagu, E.; Björklöf, T.; Fagerlund, J.; Wärnå, J.; Geerlings, H.; Zevenhoven, R.; Miner. Eng. 2012, 30, 75.

66. Sanna, A.; Wang, X.; Lacinska, A.; Styles, M.; Paulson, T.; Maroto-Valer, M. M.; Miner. Eng. 2013, 49, 135.

67. Teixeira, A. P. C.; Santos, E. M.; Vieira, A. F. P.; Lago, R. M.; Chem. Eng. J. 2013, 232, 104.

68. Teixeira, A. P. C.; Purceno, A. D.; Barros, A. S.; Lemos, B. R. S.; Ardisson, J. D.; Macedo, W. A. A.; Nassor, E. C. O.; Amorim, C. C.; Moura, F. C. C.; Hernández-Terrones, M. G.; Portela, F. M.; Lago, R. M.; Catal. Today 2012, 190, 133.

69. Teixeira, A. P. C.; Purceno, A. D.; de Paula, C. C. A.; da Silva, J. C. C.; Ardisson, J. D.; Lago, R. M.; J. Hazard. Mater. 2013, 248-249, 295.

70. Lemos, B. R. S.; Soares, A. R.; Teixeira, A. P. C.; Ardisson, J. D.; Fernandez-Outon, L. E.; Amorim, C. C.; Lago, R. M.; Moura, F. C. C.; Chemosphere 2016, 159, 602.

71. Lemos, B. R. S.; Teixeira, A. P. C.; Ardisson, J. D.; Macedo, W. A. A.; Fernandez-Outon, L. E.; Amorim, C. C.; Moura, F. C. C.; Lago, R. M.; Appl. Sci. 2012, 2, 513.

72. Ranđelović, M. S.; Momčilović, M. Z.; Nikolić, G.; Đordević, J. S.; J. Electroanal. Chem. 2017, 801, 338.

73. Gaggero, L.; Ferretti, M.; J. Environ. Manage. 2018, 216, 246.

74. Kim, Y.-C.; Hong, W.-H.; Waste Manage. 2017, 64, 272.

75. Bonifazi, G.; Capobianco, G.; Serranti, S.; J. Hazard. Mater. 2018, 344, 981.

76. Kusiorowski, R.; Zaremba, T.; Piotrowski, J.; Gerle, A.; J. Therm. Anal. Calorim. 2013, 113, 179.

77. Mackenzie, K. J. D.; Meinhold, R. H.; J. Mater. Sci. 1994, 29, 2775. 
78. Addison, J.; McConnell, E. E.; Regul. Toxicol. Pharmacol. 2008, 52, S187.

79. Boulanger, G.; Andujar, P.; Pairon, J.-C.; Billon-Galland, M.-A.; Dion, C.; Dumortier, P.; Brochard, P.; Sobaszek, A.; Bartsch, P.; Paris, C.; Jaurand, M.-C.; Environ. Health 2014, 13, 59.
80. Guo, X.; Xiang, D.; Duan, G.; Mou, P.; Waste Manage. 2010, 30,4 .

Submitted: March 16, 2019

Published online: September 4, 2019 